\title{
An empirical evaluation of the effectiveness of South African investment analysts
}

\author{
R.F. Knight \\ Department of Accounting, University of Cape Town, Rondebosch
}

J.F. Affleck-Graves

Graduate School of Business, University of Cape Town, Rondebosch

\begin{abstract}
Investment and financial analysts are paid by society to seek information relevant to the valuation of listed com. panies. If they are performing their function correctly then, in a competitive environment, their actions will result in correctly and fairly priced securities. In this article evidence is presented that shows that South African analysts are not fulfilling this important task. In particular, evidence is presented that indicates that South African analysts are not equally adept at anticipating superior earnings performance and poor eamings performance. In general, they appear to be unduly pessimistic with regard to poorly performing companies. The result is that these companies, on average, show a marked decline in abnormal returns during the year followed by an upward reaction during the week of their preliminary announcement. As far as companies with superior earnings performance are concerned, analysts demonstrate no anticipatory ability whatsoever with the result that the only reaction observed is in the week of announcement. These results are contrasted with similar results from the NYSE clearly demonstrating that South African analysts are less perceptive than their American counterparts.

S. Afr. J. Bus. Mgmt. 1985, 16: $157-160$
\end{abstract}

Investerings- en finansiële analiste word deur die gemeen. skap betaal om relevante inligting $m$.b.t. die evaluering van genoteerde maatskappye te bekom. Indien hulle korrek funksioneer, sal hulle sekuriteite redelik en korrek prys in 'n mededingende omgewing. In hierdie artikel word bewyse voorgelé wat duidelik toon dat Suid-Afrikaanse analiste nie hierdie belangrike taak verrig nie. Daar word, meer spesifiek, aangetoon dat Suid-Afrikaanse analiste nie tot 'n gelyke mate in staat is om superieure winsprestasie en swak winsprestasie te voorsien nie. Oor die algemeen is hulle oor. matig pessimisties oor swakpresterende maatskappye. Die gevolg is dat sulke maatskappye oor die algemeen 'n merkbare afname in abnormale terugvioei toon gedurende die jaar, gevolg deur 'n opwaartse reaksie gedurende die week van voorlopige bekendstellings. In soverre as wat dit maatskappye met 'n superieure prestasie raak, toon analiste geen voorspellingsvermoë nie, met die gevolg dat die enigste reaksie tydens die week van bekendstelling bemerk kan word. Hierdie resultate word gekontrasteer met soortgelyke resultate van die New Yorkse aandelemark en toon duidelik dat Suid-Afrikaanse analiste minder insigryk is as hulle Amerikaanse eweknie.

S.Afr. Tydskr. Bedryfsl. 1985, 16: $157-160$

\section{R.F. Knight*}

Department of Accounting, University of Cape Town, Private Bag, Rondebosch, 7700 Republic of South Africa J.F. Affleck-Graves

Graduate School of Business, University of Cape Town,

Private Bag, Rondebosch, 7700 Republic of South Africa

*To whom correspondence should be addressed

\section{Introduction}

There are at least two major roles of a capital market such as the Johannesburg Stock Exchange (JSE). Firstly, it allows for a separation of the ownership and the management of resources in such a way that those economic agents with a comparative advantage in the deployment of these various resources are able to take all relevant production decisions. Secondly, it provides a mechanism whereby individual investors are able to optimize the satisfaction of their consumption patterns through the exchange of shares.

The pricing mechanism in a share exchange results in the channelling of scarce resources from saving surplus units to savings deficit units which ideally results in an optimal allocation of these resources among firms and an optimal allocation of shares among investors. Since share prices provide a signalling system in this marshalling of resources in the economy, it is imperative that these prices reflect all relevant information on the firm's prospects for the market to operate effectively.

In this context it is convenient to characterize the role of share analysts (and fund managers) in an informational way. Society pays these agents to seek out information relevant to the evaluation of firms from all sources. These information sources include official company announcements (e.g. preliminary earnings reports), non-official company sources (e.g. direct interviews with management) and non-company sources (e.g. industrial reports). Information, like other commodities, is of course costly, therefore analysts will only seek information to the point where the expected marginal cost equals the expected marginal return from the search activity. Even the most efficient market will reflect only cost-effective information. Analysts compete among themselves so that the information search activity itself is kept efficient. The various sources of information may likewise be viewed as competing with each other.

In such a setting it is obvious that the arrival of new information will be impounded instantaneously into share prices. The speed of the market's reaction to the arrival of new data therefore indicates the efficacy of the analysts and the informativeness of the data source. Indeed, from a theoretical standpoint it is trivial to show that the presence of even one highly sophisticated analyst would be sufficient to ensure an extremely rapid adjustment to a new price level which represents the new economic value of the firm in the light of the additional information provided. Nevertheless this process is likely to become more efficient as the number of market participants increases.

In this article we will focus attention on both the speed and 
the direction of the movement of share prices in response to the release of corporate preliminary announcements. In fact, by examining time periods before and after the date of the announcement we are able to determine both the predictive ability and the interpretive ability of investment analysts on the JSE. In addition, by comparing the behaviour with that observed on the New York Stock Exchange we are able to measure the relative ability of analysts on the JSE vis-a-vis their American counterparts. More specifically, in this article we examine the effect that the preliminary report has on the price of shares quoted on the JSE.

\section{Research design}

\section{Sample selection}

To execute a study of this nature three types of data are required:

(i) Exact announcement dates of preliminary results.

(ii) Weekly share price data for a reasonable period of time for all companies included.

(iii) Earnings data for these companies over a similar period.

All firms quoted in the industrial sector of the JSE for the entire period for which share data were available on the University of Cape Town data bank (viz. 2 February 1973 14 November 1980) were requested to supply the exact date of the announcement of all preliminary results in this period. Forty-one companies responded and these constituted the sample used in this study (Appendix 1). This resulted in 241 announcements being available for the study period.

\section{Methodology}

In order to examine the effect the announcements have on share prices, the methodology used by Ball and Brown (Ball \& Brown, 1968) was adopted. This methodology is briefly described below.

Firstly, for each share the effect of market-wide movements which effect all shares and which have nothing to do with the specific preliminary announcement was removed using the familiar market model approach (Fama, Fisher, Jensen \& Roll, 1969). This involves the use of ordinary least-squares (OLS) regression to estimate the parameters $\alpha$ and $\beta$ of the market model for each individual share as follows:

$R_{i t}=\alpha_{i}+\beta_{i} \cdot R_{m t}+e_{i t}$

where $R_{i t}$ is the realized rate of return on share $i$ in week $t$; $\boldsymbol{R}_{\boldsymbol{m} t}$ is the realized rate of return on the market portfolio in week $t$ (the RDM ' 100 ' Industrial Index was used as a surrogate for the market portfolio); $\alpha_{i}, \boldsymbol{\beta}_{i}$ are the regression parameters for the $i$ th share; and $e_{i t}$ is the residual term which is assumed to satisfy the OLS assumptions.

Secondly, for each particular share, an earnings expectations model was extimated as follows:

$\Delta E_{i t}=\gamma_{i}+\delta_{i} \Delta E_{m t}+f_{i t}$

where $\Delta E_{i r}$ is the percentage change in EPS for share $i$ in year $t ; \Delta E_{m t}$ is the percentage change in the average reported EPS of the market portfolio in year $t ; \gamma_{i}, \delta_{i}$ are the intercept and slope parameters respectively, specific to share $i$ and which were estimated using OLS regression; and $f_{i t}$ is the residual term which is assumed to satisfy the requirements for OLS regression.

Using the OLS estimates of $\gamma_{i}$ and $\delta_{i}\left(\hat{\gamma}_{i}\right.$ and $\left.\hat{\delta}_{i}\right)$, estimates of the $f_{i t}$ can be obtained as

$f_{i t}=\Delta E_{i t}-\left(\hat{\gamma}_{i}+\hat{\delta}_{i} \Delta E_{m t}\right)$

where the terms are as defined previously.
The purpose of the methodology is that the $\hat{f}_{\text {it }}$ can be used as a surrogate indicator of unexpected earnings. The reason is that it is not sufficient merely to conclude that because earnings in a particular year have risen that this indicates unexpectedly good news to the investor. It is well accepted that share prices reflect investors' expectations and hence the share price immediately prior to the announcement will reflect the average expectation of all investors as to what earnings will actually be.

Any price reaction will thus depend not on whether earnings are up or down on last year's earnings but rather on whether the earnings are above or below the market's expectations. It is this expectation which the above model attempts to capture and each $\hat{f}_{i t}$ will indicate whether the announcement in that year for that particular security represents unexpectedly good news $\left(\hat{f}_{i t}>0\right)$ or unexpectedly bad news $\left(\hat{f}_{i t}<0\right)$.

The third phase of the methodology is to divide the announcements into two portfolios, one comprising all 'good news' announcements (i.e. all $\hat{f}_{t t}>0$ ) and the other comprising all 'bad news' announcements. The performance of such portfolios can then be compared over a long period to observe the relative behaviour of each. This is done by using the familiar API metric (Ball \& Brown, 1968) which is calculated as:

$\operatorname{API}_{W}{ }^{g}=\prod_{n=1}^{N} \prod_{i=-50}^{w}\left(1+\hat{e}_{i n}\right)$

where: $\mathrm{API}_{w}{ }^{8}$ is the 'Abnormal Performance index of the good news portfolio in week $w$ relative to the announcement; $N_{g}$ is the number of 'good news' announcements in the study; and $\hat{e}_{i n}$ is the abnormal return of the $n$th good news announcement in the $i$ th week relative to the announcement (obtained from (1)).

$\mathrm{API}_{w}{ }^{b}$ is similarly defined for 'bad news' announcements.

It should be clear that $\mathrm{API}_{w}{ }^{g}$ represents the performance of a portfolio with an initial investment of a nominal one rand comprising equal rand amounts in each of the 'good news' announcements. Note that the performance measured is the abnormal return; that is, after the removal of all market effects. If these market movements were not removed they would possibly confound the results as it would not be clear whether any trends observed were due to the announcement itself or due to other market factors such as a change in interest rates. Also note that the $\mathrm{API}_{w}{ }^{g}$ portfolio will include shares held over a 76-week period commencing 50 weeks prior to the release of the preliminary report. Because the information contained in the preliminary report is used to partition the announcements into the two portfolios, it is clear that this article does not provide a test of an actual trading strategy. Rather, it enables us to observe whether there is any anticipation in the share price of the information contained in an announcement.

Finally, also note that a particular share used in this study will be included in the 'good news' portfolio in some years (when its $\hat{f}_{i r}>0$ ), whereas in other years it will be included in the 'bad news' portfolio. Thus, the API provides a measure of the average performance of the good news announcements where the averaging is done both across firms and through time (years). (For further details of the research methodology the reader is referred to Ball \& Brown, 1968 and Knight, 1983).

\section{Results}

The API for each of the two portfolios are plotted in Figure 1. The results are extremely interesting and three aspects in 


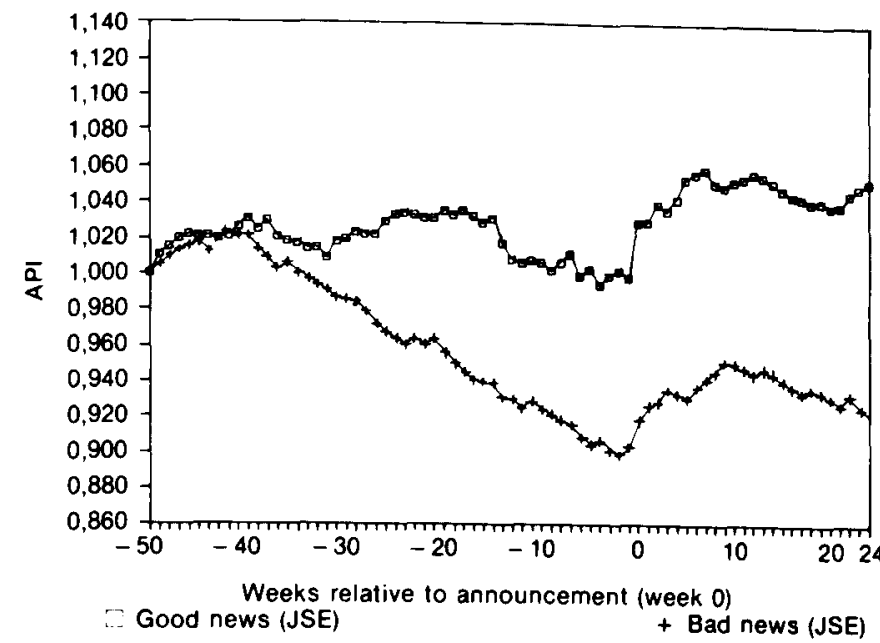

Figure 1 API plots of JSE portfolios.

particular must be highlighted.

(i) There is clear evidence of an asymmetric reaction on the JSE. This follows as the API of the 'good news' portfolio remains fairly constant during the 50 weeks prior to the release of the preliminary report. This would be consistent with the absence of additional information and a lack of predictive ability by market analysts. However, the bad news portfolio gives rise to an API series which declines steadily during the 50 weeks prior to the preliminary report. This indicates a degree of predictive ability by market analysts and is consistent with a situation where the information contained in the preliminary report has been gained or perceived by analysts from other sources such as company analysis, observation, etc. It would thus appear that analysts on the JSE are able to anticipate bad news and this is therefore impounded in the price before the preliminary report is released. But, they are not able to similarly predict those companies which will have above average performance.

(ii) For both the good news and the bad news portfolios there is a positive abnormal return, on average, in the week of the announcement. This would indicate that for both groups, the effect of the preliminary announcement has, on average, resulted in an upward adjustment of the share price. Given the asymmetric result referred to in (i) above, this is an expected result for the good news portfolio which, after all, contains those securities that had unexpectedly good news earnings announcements. However, for the bad news portfolio such an explanation is not valid and the only conclusion one can reach is that the bad news companies are perceived to be even worse than they actually are. Thus, when the preliminary report is released there is an upward adjustment from the previous unnecessarily pessimistic position.

(iii) The post-announcement period is characterized by fairly flat API plots consistent with little or no further information. In this respect the results presented in Figure 1 indicate market efficiency in that the reaction to the announcement takes place within the week of the announcement (i.e. almost instantaneously). Thereafter the API plots reflect a situation consistent with that of no further information or impounding of previously released information.

In summary therefore, the results presented above indicate that investors on the JSE are reasonably efficient in that once new information is released, share prices adjust rapidly to a new equilibrium level. In addition, they appear to be able to isolate poor performance companies before the actual release of information indicating this poor performance. However, they do appear to be unnecessarily pessimistic in these cases. Finally they do not appear to be able to consistently isolate those companies that will have unexpectedly high earnings in a year and hence price adjustment for this group only takes place once the results have been released. This would suggest a certain lethargy on the part of South African analysts in that alternative information sources are not being adequately exploited for this group of companies.

\section{Comparison with the NYSE}

The Ball and Brown (Ball \& Brown, 1968) study presented similar tests for the New York Stock Exchange (NYSE) and their results are summarized in Figure 2.

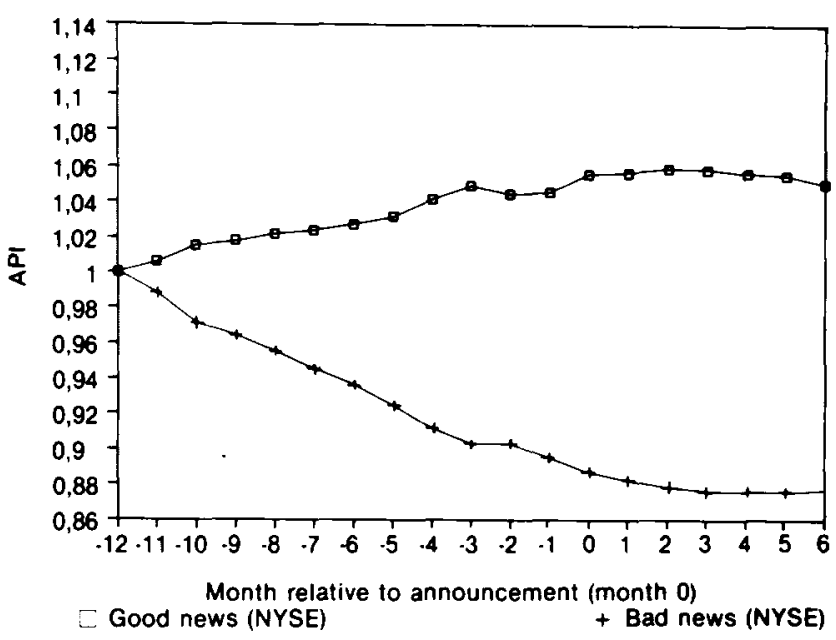

Figure 2 API plots of NYSE portfolios.

It is immediately apparent that their results are different from those obtained on the JSE in that there is clearly, a symmetric reaction. Thus on the NYSE analysts appear able to isolate both good and bad news companies before the actual release of the preliminary reports. In addition, there is no evidence of any reaction in the API in the actual week of the announcement or subsequently. Thus, it would appear that on the NYSE analysts not only can identify both good news and bad news companies but in addition, they obtain all the price-relevant information contained in the preliminary report from alternative sources prior to its release.

The conclusion that can be drawn from these results is that analysts on the NYSE are superior to analysts on the JSE in that they are better able to price shares correctly prior to the release of information. However, it should be noted that the NYSE operates in a richer information environment than does the JSE and thus a number of institutional differences may explain the different results. For example, companies quoted on the NYSE produce quarterly reports (as opposed to half yearly on the JSE), many institutions and services exist that provide additional information such as forecasts of future earnings and beta estimates, information costs on the NYSE may be considerably lower than on the JSE, etc.

\section{Conclusions}

In this article we have focused attention on the reaction of share prices around the time of the release of the preliminary report. We are able to show that the market reacts fairly rapidly to the earnings information provided by such reports. This indicates consistency with the semi-strong form of the 


\section{Efficient Market Hypothesis (EMH).}

We are also able to show that the market is fairly adept at anticipating those companies that are likely to produce inferior financial results. However, in doing so the market appears to take an unnecessarily pessimistic view of the situation with the result that the release of the preliminary report is accompanied by, on average, an upward adjustment in the market price of a poorly performing company.

Conversely, the market appears unable to anticipate in any way those companies achieving superior performance. Thus, for these companies all of the market reaction appears to come after the release of the preliminary report.

Finally, it would appear that financial and investment analysts on the JSE are not nearly as perceptive as are their American counterparts. Given that one of their functions to society is to ensure that shares are priced correctly and fairly, one must seriously question whether the local analysts are in fact fulfilling this role.

\section{References}

Ball, R. \& Brown, P. 1968. An Empirical Evaluation of Accounting Income Numbers. J. Account. Res., vol.6, $159-178$.

Fama, E., Fisher, L., Jensen, M. \& Roll, R. 1969. The Adjustment of Stock Prices to New Information. Int. Econ. Rev., vol.10, 1-21.

Knight, R.F. 1983. The Association Between Published Accounting Data and the Behaviour of Share Prices. Unpublished Ph.D. thesis, University of Cape Town, $400 \mathrm{p}$.

\section{Appendix 1}

1. AECI Limited

2. African Oxygen Limited

3. Anglo Alpha Limited

\section{Appendix 1 (continued)}

4. Anglo American Industrial Corporation Limited

5. Barlow Rand Limited

6. Beares Limited

7. Blue Circle Limited

8. Bonmore Investments Limited

9. Boumat Limited

10. Carlton Paper Corporation Limited

11. Chemical Holdings Limited

12. Dorbyl Limited

13. Dunlop South Africa Limited

14. Edgars Stores Limited

15. Everite Limited

16. Federale Voedsel Beperk

17. Federale Volksbeleggings Beperk

18. Foschini Limited

19. Frasers Limited

20. Gallo (Africa) Limited

21. General Tyre \& Rubber Co. (South Africa) Limited

22. Huletts Corporation Limited

23. Kaap Kunene Beleggings Beperk

24. Kohler Brothers Limited

25. Malbak Limited

26. Metal Box South Africa Limited

27. Metcash Limited

28. Murray \& Roberts Holdings Limited

29. O.K. Bazaars (1929) Limited

30. Otis Elevator Co. Limited

31. Pick 'n Pay Stores Limited

32. Plate Glass \& Shatterprufe Industries Limited

33. Protea Holdings Limited

34. Rennies Consolidated Holdings Limited

35. Reunert \& Lenz Limited

36. Seardel Investment Corporation Limited

37. Sentrachem Limited

38. Stewarts \& Lloyds of South Africa Limited

39. Toyota (South Africa) Limited

40. Trek Beleggings Beperk

41. Woolworths Limited 